\title{
CORRUPTION AS A CONTAGIOUS PSYCHOSOCIAL DISORDER, A CONCEPTUAL ANALYSIS
}

\author{
ABDULBAGHI AHMAD, MBCHB, SBCAP, PHD*
}

\section{Submitted 13 March 2019; accepted 30 September 2019}

\section{ABSTRACT}

Background: Corruption is defined as the abuse of entrusted power for private gain. It is a world-wide phenomenon, particularly in the developing societies. It has been mentioned as a cause of destruction of many empires and powerful states in the history. No effective evidence-based prevention or treatment has been identified, yet. The objective of this study is to describe a conceptual framework using psychosocial analysis based on current scientific theories to explain corruption as a contagious psychosocial disorder to be correctly diagnosed, prevented and treated.

Methods: This is a theoretic conceptual analysis describing corruption for the first time in terms of contagious psychosocial disorder. The sample concerns structural and functional positions at the Child Mental Health Center (CMHC) in the city of Duhok, Kurdistan region of Iraq (KRI) during December 2018 - February 2019. No experimental or clinical data are included. Accordingly, a package of Psychosocial Anti-Corruption Tools (PACT) is presented as an intervention to replace identified actions of corruption.

Results: Specific diagnostic criteria, such as: Illegal or un authorized gain, more than one salary, unjustified power position...etc., are found to classify corruption as a contagious psychosocial disorder according to current theories concerning a etiology, pathogenesis, clinical picture, consequences, prevention and treatment. This is the first pilot project that has been started at a governmental organization.

Conclusions: Corruption can be Hypothesised as a contagious psychosocial disorder to be tested in further rigorous research in other cultures, societies, and countries where corruption is prevailing.

Duhok Med J 2020; 14 (1): 19-27.

Keywords: Corruption, Psychosocial disorder, Conceptual framework. Psychosocial AntiCorruption Tools (PACT)

orruption is the abuse or complicity
in abuse, of public or private position, power or authority to benefit oneself, a group, an organization or others close to oneself; where the benefits may be financial, material or non-material ${ }^{1}$. History is telling us about various models of different empires and powerful regimes that collapsed because of the elements of corruption that contaminated all its joints. Still, the phenomenon of corruption continues with all its types to be one of the most important structural problems that developing societies experience ${ }^{1}$, particularly in any society undergoing rapid social transition from a closed collective system to an open developing society, as it is the case in the Iraqi Kurdistan $^{2}$. Wasta (distribution of favours among family, friends and tribe) is representing one of the largest sources of corruption in several countries in the Middle East $^{3}$. It has been shown to be psychologically more beneficial to the givers of corruption than to the receivers. In all its categories and methods,

* As s ociate Professor, CAP, Upps ala University, Uppsala, Sweden.

Founding Director, Metin Health House for Child Mental Health, Duhok, Kurdistan Region, Iraq.

Correspondence author: Abdulbaghi.Ahmad@Neuro.Uu.SeMobil+46702212155, or +9647504461114 
corruption has shown to be contagious and transmittable from upper to lower levels in the hierarchy of power. Although it usually violates the cultural and psychosocial values in a specific society, corruption in developing countries is rather becoming a norm than exception in all sectors of the society. We include only references related to corruption in the health and medical practice $^{4-8}$ which is the scope of this paper. The 2010 World Health Report stated that an estimated $20-40 \%$ of potential health gains from health spending are lost through inefficiencies ${ }^{5}$. More corruption is associated with worse health outcomes ${ }^{6}$. The potential gains from fighting corruption-such as more and better healthcare, stronger judiciaries and legitimate politics - are immense ${ }^{7}$. Comprehensive frameworks and sets of methodologies for describing and measuring how opportunities, pressures and rationalizations influence corruption in the health sector have been described ${ }^{8}$. When salaries in a society are inadequate to pay for basic necessities, corruption has been considered a 'coping mechanism' and has been described as 'survival corruption'1. Previous interventions to reduce corruption showed high risk of bias, and either low or very low certainty of the evidence ${ }^{1}$. To our knowledge, this is the first study to be published describing corruption as a psychosocial disorder.

This conceptual analysis is an attempt to find out a medical context of corruption as a contagious psychosocial disorder to be diagnosed and treated accordingly.

\section{METHODS}

Sample: The sample consists of the CMHC in Duhok city in the Kurdistan Region of Iraq (KRI) during the study time December 2017 - February 2019.We have chosen this sample because of the accessibility, feasibility and eligibility reasons. The CMHC started as a modern independent organization before it became integration in the governmental system. Being a conceptual theoretic study, no personal data are included in this analysis. Data collection concerning structural and functional positions are to be presented in separate papers when results of pre and post assessments are available. Regardless if the employees were aware or not, the governmental system was directly or indirectly encouraging different types of activities included in the corruption concept, such as Waste, bribe, favoritism, nepotism..etc. The dominating action of corruption was consisting of working for external employer during the time assigned for the governmental employment in order to receive double salaries for the same working time.

Conceptual Psychosocial Analysis:

Corruption is considered as a contradictory subject related to the individual's values, emotions and behavior adjusted to a social context where an authoritative system is running against its current laws and cultural values. Corruption is wide-spread in different administrative, occupational or political forms in different countries in the world. And it seems to have different cultural implications leaving various impact on different societies. Similar to any other contagious disease, corruption is transmitted to any active person in the social life of a corrupt system. The etiological link between corruption and 
contageousity is suspected in psychosocial interpersonal factors. So far, no organic or microbiological agent is identified. epidemic infectious diseases were considered first as unfair or antisocial actions performed by high powers or powerful people before they became scientifically discovered as diseases, such as Smallpox, Measles, Plague, Syphilis, and last but not least Acquired Immune Deficiency Syndrome (AIDS). The current technical and scientific development is facilitating an early identification of the sources and mechanisms of health and illness. Most of the chronic medical conditions have multifactorial aetiology including bio-psycho-social components. A big deal of the psychosocial interference starts during early childhood through social media and globalization. Child education builds up the cognitive capacity to designs basic values from early childhood. The influence of values and personality development have been good market for selling recent ideologies and modern social norms instead of the oldfashioned violence creating war and conflicts. Human rights, freedom of expression and democratic values are replacing racism, extremism and totalitarian leadership. Psychological warfare and brain washing operations are becoming more popular than classical war to solve conflicts. Accordingly, clear-cut corruption is gradually becoming more subtle and complicated. Healthy personality development is increasingly becoming a big challenge for health and medical systems. The interaction between biology, psychology and social sciences is producing more sustainable and rational grounds for salutogenesis instead of pathogenesis. This is making the time mature to apply medical theories not only for description of psychopathology but also to explain complicated psychosocial phenomena, such as corruption.

A common act of corruption is that the employed person in a governmental organization is leaving his/her ordinary work for a determined period to work with an external so called out-reached job. The aim is to obtain extra money from another employer in addition to the ordinary governmental salary. The argument is that a current economic crisis in the region is preventing the government to pay full salaries. In this case, the employed person's argument is strong enough since the government is unable to provide complete salary. Accordingly, the employed person is receiving two salaries for the same working hours, i.e. abusing public position to benefit oneself (Memorandum from the author as Advisor to the Director General of Duhok Health).

Psychosocial Anti-Corruption Tools (PACT):

In order to conceptualize and operationalize an intervention for prevention and treatment of corruption as a psychosocial disorder, following instruments have been developed:

1- Compensation for the Out-reached Time (COT): The ordinary employer might consider the absence period of the employed person from the governmental organization as an unpaid vacation to feel support instead of remorse and shame about the duties left behind.

2- Considering Out-reached Service as Training (COST): The employer might consider the out-reached work as 
training for the benefit of the ordinary governmental organization. The employed will achieve new skills and feel pride rather than evasion and denial.

3- Effective Time Utilizing (ETU): A time table has to be established for every employed person to accomplish the duties without external interference. It gives the employee a meaningful engagement in the work during the official working hours, feeling value and significance in serving the community.

4- Receiving Satisfied Consumers (RSC): The employed has to give sufficient time in meeting with the consumers to provide services fairly, successfully, and effectively. Receiving satisfied consumers will encourage the employee to continue working sincerely.

5- Specialized Referral System (SRS): Adequate selection of the clients to be referred for suitable specialized services will deliver the right service to the right person. The employed will feel comfortable and reassured to perform the duties within his/her power and ability. This will lead to psychological attachment with the work and a sense of control to prevent psychological distress that corruption entails.

6- Team Work (TW): Mixing up different disciplines and professions to deliver services in consensus and justice. Being a member of the team will strengthen self-confidence and trust with colleagues, leading to early detection of symptoms of corruption to be prevented or treated as early as possible.

These are open individually adjusted agreements to be written and signed by the responsible director and the individual employee. No prior schedule or questionnaire is needed. On achievement, the results will be de-identified, operationalized, computerized and conceptualized to be available for quantitative and qualitative analysis.

\section{ETHICAL CONSIDERATION}

This study includes no individual interview or personally identifiable data collection. Some employees at the CMHC initially protested against using corruption term in their organization. Several meetings were needed to inform on ethical conflicts and to clarify any misunderstanding. The German Society for International Cooperation (GIZ) financially supported this project.

\section{EXPECTED RESULTS}

Following results have been hypothesized to be achieved from the conceptual psychosocial analysis of corruption as a psychosocial disorder:

A- Aetiology: Following psychosocial interpersonal factors are suggested as potential causes or predisposing factors for corruption:

1- A decline in the old standards of values and ethics in a society that undergoes rapid social transition when modern alternative standards have not been formed, yet.

2- Development of a weak individual personality because of the oldfashioned child education based on three destructive principles (fear, shame, and $\sin$ ).

3- An administrative authority without scientifically planed programs, due to 
the incompetent leadership that emerged from the armed struggle.

4- A prevailed ignorance in the society.

B- Pathogenesis: Corruption is assumed undergoing following stages to become a full-established disorder:

1- Favoring pleasure (such as sex, power, and money) over law, ethics and rights leads to oblivion and neglect of risks.

2- Not dealing rationally with the situation due to lack of competence or inability to contain the event, or providing reasons related to ancient cultural values.

3- Direct or indirect encouragement from the surrounding environment.

4- Working within a corrupt system.

C- Clinical Picture: If one of these signs and symptoms appears on a person, you might suspect the appearance of corruption and work on alerting and preventing it:

1- Any behavior illegally practiced by the individual at the expense of society.

2. A gain without justified work or efficiency that the person deserves.

3 - Get two salaries from two different sides for a determined period of time.

4 - Supporting or facilitating a gain without appropriate merit.

The dominance of pleasure (such as sex, power, and money) over law, morality, and rights, leading to forgetting or neglect of risks.

D- Consequences: Corruption has been expected to lead to the following consequences:

1. The spread of poverty and lack of justice in the community.

2. Deficit sense of individual responsibility.
3. Increased hate, disgust and violence in the society.

4. Destruction of public institutions, government system, administration rules, services and authority.

E- Prevention: Following steps might be taken to prevent corruption:

1. Access to information, knowledge and facts about this devastating contagious disease.

2 - Stay away from corrupt systems and people affected by this disorder.

3 - Warning others when knowing scientific facts about contamination.

4- Working peacefully and scientifically to combat this disorder.

F- Treatment: In addition to the abovementioned intervention tools to address corruption in any system, the following actions should be taken when suspecting corruption disorder:

1. Staying away from the corrupt system.

2. Diagnosing the disease by specialists and dissemination of information and guidance on corruption and how to combat it.

3. Working on providing anti-corruption tools in professional and peaceful ways.

4- Participating in peaceful activities and organizations to combat corruption and not to remain silent about its harm to the individuals and society.

Similarly to treatment of any other contagious disease during an epidemic outburst, the patient affected by corruption must be treated and not punished for being affected. This treatment might be provided in collaboration with the health system and other related governmental authorities such as those responsible for justice and security. When the treated patient is shown 
to have been acted against law, then relevant courts have to be involved.

\section{DISCUSION}

A conceptual framework considering corruption in a theoretic context as a contagious psychosocial disorder seems to produce hypothesis-generating findings at the governmental CMHC in Duhok, KRI. These hypotheses are to be tested in appropriate studies not only at the CMHC or other organisations in Kurdistan but also in other parts of Iraq or other countries where corruption is prevailing as an administrative, occupational, social or political problem. Accordingly, an intervention program with a package of Psychosocial Anti-Corruption Tools (PACT) has been developed for prevention and treatment of corruption. Following tools are included: 1(Compensation for the Out-reached Time (COT), 2(Considering Out-reached Service as Training (COST), 3(Effective Time Utilizing (ETU), 4(Receiving Satisfied Consumers (RSC), 5(Specialised Referral System (SRS), and 6(Team Work (TW).

This paper presents a theoretic model considering corruption for the first time as a psychosocially contagious disorder. Thus, a limited literature was found in relation to this context $1,3-8$, and nothing at all was found considering corruption as a medical or psychosocial condition.

Corruption is similar to AIDS in terms of transmission, course and consequences. The affected person does not feel contaminated even when the symptoms appear. When a person is informed to be suspected or at risk for corruption, he/she feels sad, guilty and angry first on the informant and then on the suspected causes. This is usually followed by a tendency to deny, retaliate and using violence. That is probably because the term corruption in the Kurdistan society has gradually turned to be a humiliating and degrading as an assault to which all the society has gradually adapted from the top downwards.

When we consider corruption as a disorder, we have to fight against corruption and not against the affected person. We have to attack the disorder while treating the patient. This peaceful approach might be easier for the affected people to accept since no patient is accused for getting a disease. It also makes it easier to provide necessary prevention and early treatment before the disorder becomes chronic and difficult to treat.

Once in the history, all of the contagious diseases had irrational explanation and incurable course until the scientific evidence was able to discover a curable treatment for each of them. Still, many diseases are waiting for specific aetiology to be discovered and curable treatment to be identified. Corruption seems not to be an exception. Recent research suggests that dementia could be transferred from one person to another, and people could be unaware that they have been contaminated with Alzheimer's for up to 40 years 9 . Almost all psychiatric diagnoses still are descriptive because aetiology for most of them has not been discovered, yet. Increasingly, neuropsychiatric disorders are explained by contagion approaches suggesting foreign bodies as possible contaminating environment or transmitted from the surroundings. Psychological trauma is among the few known external 
factors contributing to a bio-psycho-social disorder called Posttraumatic Stress Disorder (PTSD) that has shown clear transgenerational transmission ${ }^{10}$. Recent research suggests a relationship between social pathologies such as gambling and traumatic childhood events as key features in indigenous populations undergoing rapid social transition ${ }^{11}$. This is in line with our previous research showing high rates of suicide in the Kurdistan region of Iraq as an indication of rapid social transition ${ }^{2}$. It might be this rapid social transition constituting the leading reason behind corruption as a contagious psychosocial disorder to be explored in further research. According to our knowledge, this is the first analysis considering corruption as a contagious psychosocial disorder. The results from the first pilot application of the PACT have been delayed because of several limitations. Hopefully, the project is going on and the evaluation is expected to show promising results to be confirmed by further rigorous independent research in many other cultures, societies or countries.

\section{REFERENCES}

1. Gaitonde R, Oxman AD, Okebukola PO, and Rada G. Interventions to reduce corruption in the health sector. Cochrane Database Syst Rev. 2016; 16(8):1-77.

2. Hanna VS, and Ahmad A. Corrected and republished: Suicide in theKurdistan Region of Iraq, state of the art. Nordic J Psychiatry. 2013; 67(2):140-144.

3. Alwerthan TA, Swanson DP, and Rogge RD.It's better to give than to receive:

Psychologicalneed satisfaction mediating links between wasta (favouritism) and individuals' psychological distress. Int J Psychol. 2018; 53 Suppl. 1:11-20.

4. Pasternak J. Corruption. Einstein (Sao Paulo). 2017; 15(3):11-12.

5. Paschke A, Dimancesco D, Taryn V, Kohler JC, and Forte G. Increasing transparency and accountability in national pharmaceutical systems. Bull World Health Organ. 2018; 96(11): 782-791.

6. Hanf M, Van-Melle A, Fraisse $F$, Roger A, Carme B, and Nacher M. Corruption kills: estimating the global impact of corruption on children deaths. PLoS One. 2011;6(11):e26990. [DOI: 10.1371/journal.pone.0026990] [PMC free article] [PubMed]

7. Muldoon KA, Galway LP, Nakajima M, Kanters S, Hogg RS, Bendavid E, et al. Health system determinants of infant, child and maternal mortality: a cross-sectional study of UN member countries. Globalization and Health. 2011; 7:42.

8. Vian T. Review of corruption in the health sector: theory, methods and interventions.Health Policy Plan. 2008; 23(2):83-94.

9. Mayor S. Peptides that form amyloid plaques in Alzheimer's may be transmissible, study finds. BMJ. 2015 Sep 9; 351: h4831. doi: 10.1136/ bmj.h4831.

10. Montgomery E, Just- Østergaard E, and Jervelund SS. Transmitting trauma: a systematic review of the risk of child abuse perpetrated by parents exposed to traumatic events.Int $\mathbf{J}$ Public Health. 2018 Dec 1. doi: 
10.1007/s00038-018-1185-4. [Epub ahead of print].

11. Lytken Larsen CV, Curtis T, Bjerregaard P. Gambling Behavior and Problem Gambling Reflecting Social Transition and Traumatic
Childhood Events Among Greenland Inuit: A Cross-Sectional Study in a Large Indigenous Population Undergoing Rapid Change. Journal of Gambling Studies. 2013; 29(4): 733748. 


\section{يوخته}

كَندهله وهك تيكجونهكا دهرونجقاكى يا قهكر، شروقهكرنا قهوارهى

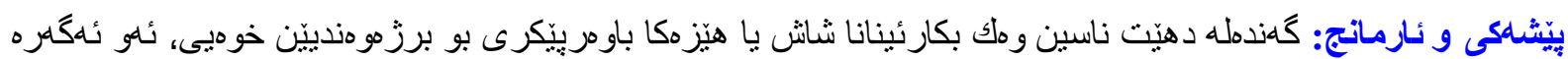

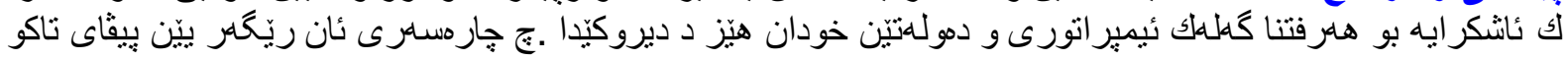

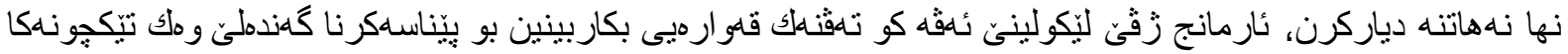

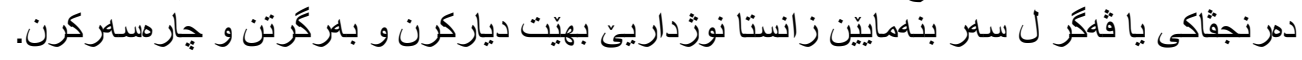

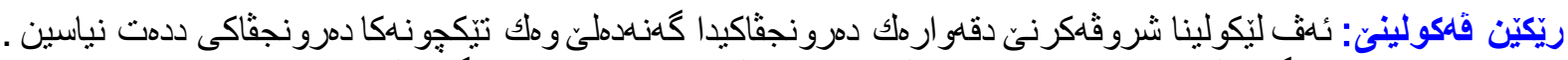

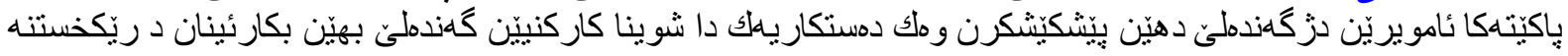

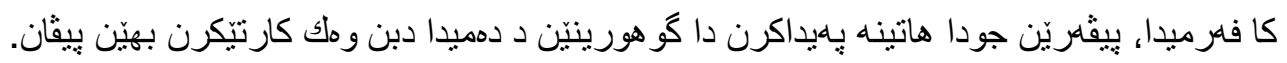

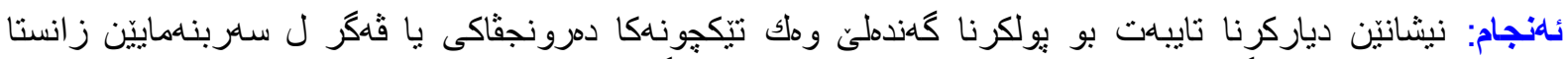

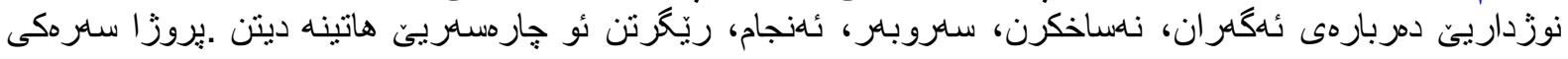

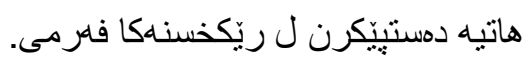

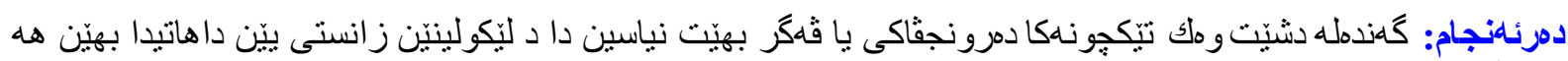
لسهنيخاندن. 


\section{الخلاصة}

الفساد كاضطراب نفسي إجتماعي مُعدِ، تحليل إطاري

الخلفية والأهداف: يعرف الفساد كإستغلال منصب قوة لأجل مصالح ذانية، وهو سبب معروف لتدمير إمبراطوريات ودول قوية عليدة

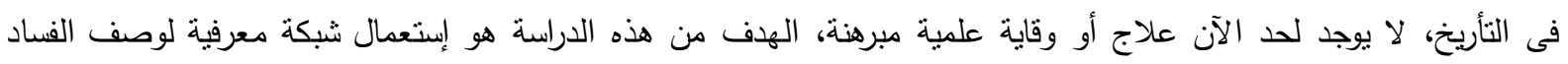

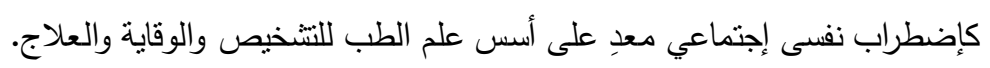
طرق البحث: هذه الدراسة تستعمل تحليل إطارى لتعريف الفساد كإضطراب نفسيإجتماعى لمجموعة من الأدوات المضادة للفي للفساد تقام فى تداخل للعمل بها بدلا من سلوكيات الفساد فى دائرة حكومية، مقاييس علمية وجدت لقياس التغيير خلاد الزمن كدليل على تأثير

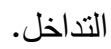

النتائج: علامات مميزة وجدت لنتخيص الفساد كإضطراب نفسى إجتماعى معد على أساس علم الطب فيما يتعلق بالأسباب والتمرض والحالة السريرية والعواقب والوقاية والعلاج، تم البدأ بالمشروع الأولى فى دائرة حكومية. الإستتتاجات: يمكن نعريف الفساد كإضطراب نفسي إجتماعي معد لكى يتم تقييمها فى الدراسات العلمية المقبلة. 